\title{
Disruption of Vector Transmission by a Plant-Expressed Viral Glycoprotein
}

\author{
Mauricio Montero-Astúa, ${ }^{1}$ Dorith Rotenberg, ${ }^{1}$ Alexandria Leach-Kieffaber, ${ }^{1}$ Brandi A. Schneweis, ${ }^{1}$ \\ Sunghun Park, ${ }^{2}$ Jungeun K. Park, ${ }^{2}$ Thomas L. German, ${ }^{3}$ and Anna E. Whitfield ${ }^{1}$ \\ ${ }^{1}$ Department of Plant Pathology and ${ }^{2}$ Department of Horticulture, Forestry and Recreation Resources, Kansas State \\ University, Manhattan 66506-5502 U.S.A.; ${ }^{3}$ Department of Entomology, University of Wisconsin, Madison 53706-1598 U.S.A.
}

Submitted 28 September 2013. Accepted 13 December 2013.

\begin{abstract}
Vector-borne viruses are a threat to human, animal, and plant health worldwide, requiring the development of novel strategies for their control. Tomato spotted wilt virus (TSWV) is one of the 10 most economically significant plant viruses and, together with other tospoviruses, is a threat to global food security. TSWV is transmitted by thrips, including the western flower thrips, Frankliniella occidentalis. Previously, we demonstrated that the TSWV glycoprotein $G_{N}$ binds to thrips vector midguts. We report here the development of transgenic plants that interfere with TSWV acquisition and transmission by the insect vector. Tomato plants expressing $\mathrm{G}_{\mathrm{N}}-\mathrm{S}$ protein supported virus accumulation and symptom expression comparable with nontransgenic plants. However, virus titers in larval insects exposed to the infected transgenic plants were three-log lower than insects exposed to infected nontransgenic control plants. The negative effect of the $\mathbf{G}_{\mathrm{N}}-\mathrm{S}$ transgenics on insect virus titers persisted to adulthood, as shown by four-log lower virus titers in adults and an average reduction of $87 \%$ in transmission efficiencies. These results demonstrate that an initial reduction in virus infection of the insect can result in a significant decrease in virus titer and transmission over the lifespan of the vector, supportive of a dose-dependent relationship in the virusvector interaction. These findings demonstrate that plant expression of a viral protein can be an effective way to block virus transmission by insect vectors.
\end{abstract}

The Bunyaviridae is a family of animal and plant viruses that threaten human health, animal husbandry and plant production worldwide, and both new and established species are currently emerging as important pathogens (de Oliveira et al. 2012; Guler et al. 2012; Herder et al. 2012; McMullan et al. 2012; Walter and Barr 2011). The epidemiology of these viruses is dependent on arthropod vectors (the genera Orthobunyavirus, Nairovirus, Phlebovirus, and Tospovirus) or rodent vectors (genus Hantavirus). The effect of climate change on vectorborne virus distribution and population dynamics suggest that bunyavirus spread and occurrence will continue to increase

Current address for M. Montero-Astúa: CIBCM and Escuela de Agronomía, Universidad de Costa Rica, San José 11501-2060, Costa Rica.

Corresponding author: A. E. Whitfield; Telephone: +1.785.532.3364;

E-mail: aewtospo@ksu.edu

* The $e$-Xtra logo stands for "electronic extra" and indicates that three supplementary figures and two supplementary tables are published online.

(C) 2014 The American Phytopathological Society
(Jones 2009; Kilpatrick and Randolph 2012; Pappu et al. 2009; Walter and Barr 2011). Likewise, increasing human population and the consequent urbanization of wild areas contribute to this problem (Jones 2009; Kilpatrick and Randolph 2012; Pappu et al. 2009; Walter and Barr 2011). Therefore, effective approaches to control these viruses are needed. Here, we present a novel control strategy to interfere with the transmission cycle of Tomato spotted wilt virus (TSWV), a plant-infecting virus in the family Bunyaviridae, genus Tospovirus, that is transmitted by several species of thrips (order Thysanoptera) (Whitfield et al. 2005).

Tospoviruses and their thrips vectors are increasing in importance worldwide. Thrips are economically important as direct plant pests that limit crop production in fields and greenhouses, and some species are expanding their geographical range, helped by, among various factors, increasing international trade and climate change (Morse and Hoddle 2006; Reitz 2009). Tospoviruses are considered emerging diseases because, in recent years, new species have been described and established species are found infecting new hosts or in geographical areas where they were not previously reported (Mandal et al. 2012; Pappu et al. 2009). TSWV is one of the top 10 plant-pathogenic viruses due to the combined effect of the damage it causes to crops and the cost of disease management (Scholthof et al. 2011). The virus has a global distribution and has a wide host range, infecting hundreds of plant species, including important commodities such as tomato, pepper, lettuce, peanut, potato, and many ornamental plants. The losses associated with TSWV and other members of this genus exceed tens of millions of dollars (Culbreath et al. 2003; Mandal et al. 2012; Pappu et al. 2009; Riley et al. 2011).

The control of TSWV and other tospoviruses relies heavily on control of vector thrips. The management of thrips pests has proved very difficult and, even when insect levels are below an economic threshold for plant damage, a few thrips are enough to transmit viruses to plants (Amin et al. 1981; Evans and Gunderson-Rindal 2003; Falk and Tsai 1985; Sutherst 2004). Resistance to certain tospoviruses mediated by $T s w$ and $S w-5$ genes is used in commercial pepper and tomato varieties, respectively. However, virus strains overcoming the resistance have been documented (Lopez et al. 2011; Margaria et al. 2004). Likewise, chemical control of thrips may not reduce tospovirus transmission (Culbreath et al. 2003; Mandal et al. 2012; Morse and Hoddle 2006; Reitz 2009). Among thrips, Frankliniella occidentalis is the most efficient TSWV vector and is an economically important pest in greenhouses and field crops (Reitz 2009). Populations of F. occidentalis have developed high levels of resistance to many insecticides, leaving few options to control thrips or the tospoviruses they can trans- 
mit (Gao et al. 2012). New control strategies against thrips and tospoviruses are required, and transgenic plants are recognized as promising options for tospovirus management (Mandal et al. 2012; Pappu et al. 2009).

The understanding of the molecular determinants of plant virus-vector interactions allows the development of novel ways to control viruses by interfering with the initial steps in the interaction. Disruption of the acquisition process renders insects incapable of transmitting the virus or greatly reduces transmission efficiency and, thus, stops the transmission cycle (Liu et al. 2010; Shao et al. 2003; Sparks et al. 2011). In the case of TSWV, it was shown that one of the virus glycoproteins, $\mathrm{G}_{\mathrm{N}}$, serves as the attachment protein of the virus (Whitfield et al. 2004). A soluble form of $G_{N}$ produced in vitro $\left(G_{N}-S\right)$ was able to interfere with the acquisition and transmission of TSWV by F. occidentalis when fed exogenously to thrips prior to or simultaneously with TSWV (Whitfield et al. 2004, 2008). These results suggest that $\mathrm{G}_{\mathrm{N}}-\mathrm{S}$ is a good candidate to deploy against TSWV. Moreover, this approach may be used against other tospoviruses by using the corresponding $\mathrm{G}_{\mathrm{N}}$ glycoproteins.

The objective of this work was to generate and characterize transgenic tomato plants expressing a soluble form of TSWV glycoprotein $\mathrm{G}_{\mathrm{N}}$ fused to green fluorescent protein (GFP): $\mathrm{G}_{\mathrm{N}^{-}}$ $\mathrm{S}:$ :GFP. We generated the fusion to GFP in order to facilitate characterization of the plants and tracking the recombinant protein. We demonstrated that the recombinant protein $\left(\mathrm{G}_{\mathrm{N}}-\mathrm{S}:\right.$ : GFP) in the transgenic plants interfered with TSWV acquisition by thrips and, as a consequence, the transgenic plants decreased virus transmission by the corresponding adult thrips. Transgenic plants carrying $\mathrm{G}_{\mathrm{N}}-\mathrm{S}$ constitute a novel tool to control TSWV spread by means of a transmission inhibition strategy.

\section{RESULTS}

\section{Generation of $\mathrm{G}_{\mathrm{N}}-\mathrm{S}$ transgenic tomato plants.}

Putative transgenic tomato plantlets were regenerated in vitro under kanamycin selection after Agrobacterium-mediated transformation of tomato calli. In total, 10 independent $\mathrm{G}_{\mathrm{N}}-\mathrm{S}$ :: GFP T0 transgenic plants (events) were obtained after transformation and in vitro culture. Six $\mathrm{G}_{\mathrm{N}}-\mathrm{S}$ ::GFP plants $(60 \%)$ were confirmed as transgenic plants by enzyme-linked immunosorbent assay (ELISA) with specific antibodies to detect the recombinant protein. Moreover, fluorescent confocal microscopy observations showed the presence of a GFP signal in those plants (Fig. 1). These $\mathrm{G}_{\mathrm{N}} \mathrm{S}$ ::GFP-expressing transgenic plants did not display deleterious phenotypes (e.g., reduced vegetative growth, flower set, or fruit yield) during growth and development (data not shown).

Seed were harvested from five $\mathrm{T} 0 \mathrm{G}_{\mathrm{N}}-\mathrm{S}:$ :GFP plants out of the six events which were confirmed to express the recombinant protein and the seed were planted to obtain T1 plants. The segregation of the transgenic phenotype (presence of recombinant protein) was evaluated by ELISA with antibodies against $\mathrm{G}_{\mathrm{N}}$ or GFP proteins. For all five T0 $\mathrm{G}_{\mathrm{N}^{-}} \mathrm{S}$ ::GFP events for which seed were planted, some proportion of the T1 seedlings tested positive for the recombinant protein (12 to 85\%). Additionally, a commercial double-antibody sandwich (DAS)-ELISA that detects the protein product of the nptII gene (kanamycin resistance marker) was used to evaluate $\mathrm{T} 1$ plants and confirmed the transgenic nature of the plant lines ( 71 to $94 \%$ of positive seedlings for neomycin phosphotransferase II [NPTII] enzyme). Fluorescent microscopy observations of leaf tissue from these $\mathrm{T} 1$ plants confirmed the presence of a GFP signal (Fig. 1).

The amount of recombinant protein accumulating in the transgenic tissue (T1) varied among the different tomato lines. The relative amount of recombinant protein accumulating in different transgenic lines was indirectly determined by quantifying the amount of GFP protein on those plants. There is a 1:1 molar ratio between $\mathrm{G}_{\mathrm{N}}-\mathrm{S}$ and GFP molecules due to the fusion nature of the recombinant protein. Therefore, the amount of GFP protein detected in each plant (500 $\mathrm{mg}$ of tissue) by a quantitative DAS-ELISA with a GFP standard curve was used to calculate the amount of $\mathrm{G}_{\mathrm{N}}-\mathrm{S}:$ :GFP. The amount of recombinant protein was 22.6 to $2400.8 \mathrm{ng}$ of $\mathrm{G}_{\mathrm{N}}-\mathrm{S}$ ::GFP per milligram of total soluble protein extracted from 17 transgenic T1 plants (Supplementary Fig. S1). The fusion of $\mathrm{G}_{\mathrm{N}}-\mathrm{S}$ to GFP enabled tracking, visualization, and quantification of $\mathrm{G}_{\mathrm{N}}-\mathrm{S}$ in planta.

\section{Detection of the recombinant protein by Western blot.}

The presence of recombinant protein and its identity was confirmed by Western blot analysis using specific antibodies against $\mathrm{G}_{\mathrm{N}}$ and GFP proteins. Bands corresponding to $\mathrm{G}_{\mathrm{N}}-\mathrm{S}$ :: GFP that migrated similarly to the $75-\mathrm{kDa}$ molecular weight marker were detected in several transgenic lines by Western blot using antibodies against $\mathrm{G}_{\mathrm{N}}$ (Supplementary Fig. S2A). The predicted molecular weight for $\mathrm{G}_{\mathrm{N}}-\mathrm{S}$ : GFP based on the nucleotide sequence of the fusion cassette was $63.4 \mathrm{kDa}$ (using the tools available at ExPASy Bioinformatics Resource Portal); however, the calculated size does not account for the glycosylation (Naidu et al. 2004) events that occur during the posttranscriptional processing of the protein. Moreover, the observed size for a previously in-vitro-produced $\mathrm{G}_{\mathrm{N}}-\mathrm{S}$ was approximately $50 \mathrm{kDa}$ (Whitfield et al. 2004) and the size for GFP is $27 \mathrm{kDa}$; thus, the $77-\mathrm{kDa}$ band is consistent with mobility of glycosylated $\mathrm{G}_{\mathrm{N}}-\mathrm{S}$ ::GFP. Bands corresponding to $\mathrm{G}_{\mathrm{N}}-\mathrm{S}$ ::GFP were also detected with antibodies against GFP. The commercial GFP antibody had a stronger reaction to the $\mathrm{G}_{\mathrm{N}}-\mathrm{S}: \mathrm{GFP}$ fusion protein than the anti- $\mathrm{G}_{\mathrm{N}}$ peptide antibody, and the recombinant protein was detected with anti-GFP antibody in all tested plants. The relative intensity of the bands varied among samples, despite adding equal quantity of protein, suggesting different levels of recombinant protein content among different transgenic lines and generations, and was in agreement with the quantification data. In the TSWV-positive control sample and in several of the transgenic samples, a double band was observed for $G_{N}$ or $G_{N}-S:$ GFP, suggesting that the wild-type $\mathrm{G}_{\mathrm{N}}$ and also the recombinant $\mathrm{G}_{\mathrm{N}}-\mathrm{S}$ ::GFP protein occurred as two different forms in planta. These two different forms may represent different levels of glycosylation, as was suggested by Naidu and associates (2004), who reported two molecular sizes for $\mathrm{G}_{\mathrm{N}}$, a 58- and a 53-kDa protein mass.

\section{Reaction of $\mathrm{G}_{\mathrm{N}}-\mathrm{S}:$ :GFP transgenic plants to TSWV inoculation and detection of recombinant protein in TSWV-infected plants.}

As a requisite to use $\mathrm{G}_{\mathrm{N}}-\mathrm{S}$ ::GFP transgenic plants as a transmission blocking strategy, the recombinant protein must be present during viral infection of the plant. To evaluate the reaction of $\mathrm{G}_{\mathrm{N}} \mathrm{S}$ ::GFP transgenic plants to virus infection and the co-occurrence of virus and recombinant protein in these plants, 18 transgenic T1 plants were inoculated with TSWV. Overall, ELISA of young leaf tissue from these transgenics revealed that $100 \%$ of the $\mathrm{T} 1$ plants were systemically infected 15 days after inoculation. There was no apparent association (Fisher exact test of independence, $P=1.0$ ) between the presence or absence of TSWV and the presence or absence of $\mathrm{G}_{\mathrm{N}}-\mathrm{S}: \mathrm{GFP}$ protein, regardless of leaf age tested (Supplementary Table S1). In other words, the presence or absence of one had no apparent influence on the presence or absence of the other in the T1 transgenics. Moreover, the proportion of T1 plants with detectable expression of $\mathrm{G}_{\mathrm{N}}-\mathrm{S}: \mathrm{GFP}$ in both old and young leaves for noninoculated $(43 \%)$ and TSWV-inoculated $(33 \%)$ transgenics was comparable (data not shown). If the mechanism of inhibition by $\mathrm{G}_{\mathrm{N}}-\mathrm{S}: \mathrm{GFP}$ is competition for binding to 
the thrips midgut, these findings indicate that virus and $\mathrm{G}_{\mathrm{N}^{-}}$ $\mathrm{S}:$ GFP co-occur in the tissues that the insect would be feeding on to acquire virus.

The presence of $\mathrm{G}_{\mathrm{N}}-\mathrm{S}:$ :GFP was verified using confocal microscopy for a number of plants selected from the plants that tested positive for both TSWV and $\mathrm{G}_{\mathrm{N}^{-}} \mathrm{S}:$ :GFP by ELISA. $\mathrm{G}_{\mathrm{N}^{-}}$ S::GFP fluorescent signal was observed in T1 transgenic plants that were TSWV positive (Supplementary Fig. S3). The fluorescence signal in the infected, transgenic plant tissues was not different from the one observed for noninfected transgenic plants, indicating that TSWV infection and the presence of the native viral proteins did not alter $\mathrm{G}_{\mathrm{N}}-\mathrm{S}:$ GFP expression.

\section{Transgenic $\mathbf{G}_{\mathrm{N}^{-}} \mathrm{S}$ ::GFP tomato plants interfere} with TSWV acquisition by $F$. occidentalis.

TSWV acquisition assays on TSWV-infected transgenic plants were conducted with the objective of testing the hypoth-
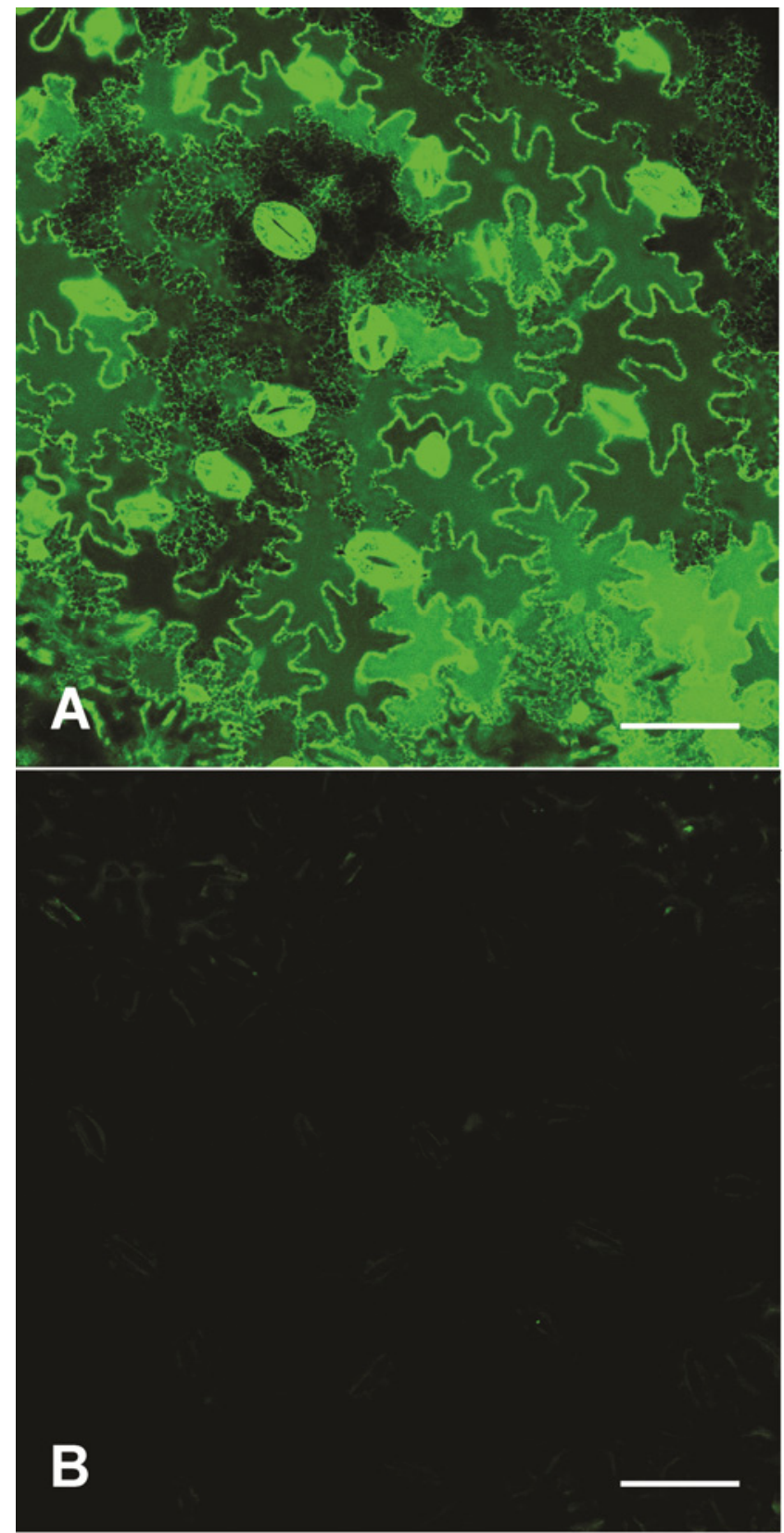

Fig. 1. A, $\mathrm{G}_{\mathrm{N}} \mathrm{S}$-GFP fluorescence on tomato transgenic plant $\mathrm{T} 1$ number 9.201. B, Control tomato plant. Green channel $(488 \mathrm{~nm})$ images. Scale bars represent $50 \mu \mathrm{m}$ esis that $\mathrm{G}_{\mathrm{N}}-\mathrm{S}:$ :GFP expression in planta will interfere with virus acquisition by thrips. The results obtained supported this hypothesis because thrips that fed on TSWV-infected transgenic $\mathrm{G}_{\mathrm{N}} \mathrm{S}$ ::GFP tomato plants had a lower virus titer than thrips fed on TSWV-infected nontransgenic plants $(P<$ 0.0001) (Fig. 2). TSWV-infected tissue was confirmed to express the recombinant protein 15 days after virus infection. Transgenic and nontransgenic TSWV-infected plants were used as virus sources to feed 0 - to 18 -h-old first-instar larval (L1) F. occidentalis. The L1 thrips were exposed to virus during an acquisition access period (AAP) of $24 \mathrm{~h}$ on tomato leaflets in water agar plates (three replicates for each treatment: transgenic and nontransgenic) and then moved to green beans for another $24 \mathrm{~h}$ to allow for virus replication in the insect body. A pooled sample of 15 thrips was picked from each replicate thrips cohort and tested by DAS-ELISA for the presence of TSWV N protein. The ELISA absorbance values for thrips fed on transgenic tissue were consistently lower than those values for thrips that fed on the corresponding nontransgenic tissue. Comparisons of the TSWV titer in the leaf tissue that was used for the thrips AAP in these experiments revealed that the transgenic and nontransgenic leaflets had similar relative virus titers. This finding indicates that the differences in virus titer in the thrips are not due to differences in the amount of virus in the tissue (Fig. 3).

Lower TSWV titers detected in thrips after feeding on transgenic TSWV plants suggested that virus infection also occurred in these groups of thrips but the degree of infection was lower in comparison with thrips fed on nontransgenic, TSWVinfected plants. The lower titer observed for a sample consisting of 15 pooled thrips may indicate i) a lower percentage of thrips infected with the virus in the cohort, ii) a lower level of infection in the individual infected thrips, or iii) a combination of these two variables. Independently of the factors contributing to the lower overall virus titer observed, the results indicate that the transgenic plants interfered with the acquisition of TSWV by F. occidentalis.

To confirm the results obtained by ELISA for groups of thrips, normalized real-time quantitative reverse-transcriptase

ELISA of thrips pooled sample $24 \mathrm{~h}$ after AAP

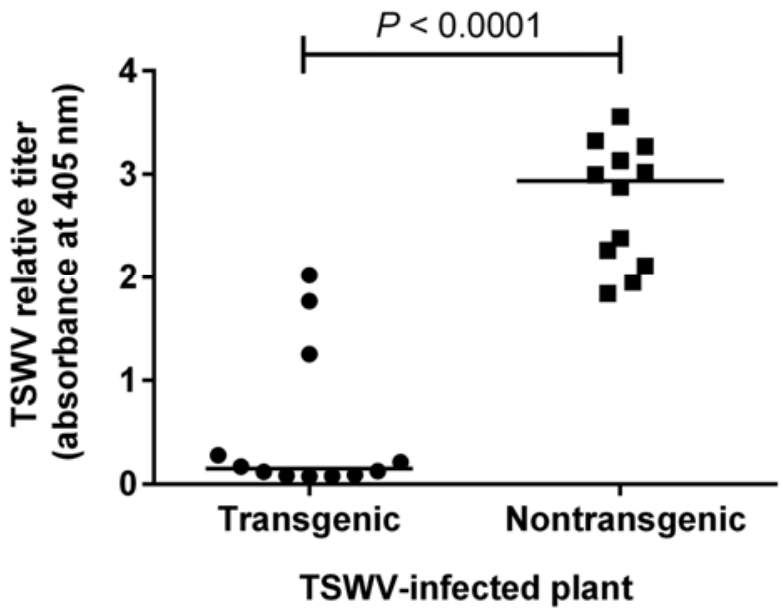

Fig. 2. Detection of TSWV nucleocapsid protein $(\mathrm{N})$ in thrips cohorts given a $24-\mathrm{h}$ acquisition access period on TSWV-infected, $\mathrm{G}_{\mathrm{N}}-\mathrm{S}$ ::GFP transgenic or nontransgenic tomato leaf tissue. TSWV was detected by double-antibody sandwich enzyme-linked immunosorbent assay in samples of pooled thrips $(n=15)$. The graph depicts 12 data points (replicates) per treatment out of four independent experiments. The horizontal line indicates the median of the data points. Medians were determined as statistically different $(P<0.0001)$ between the two treatments (transgenic or nontransgenic) by the Mann-Whitney test. 
polymerase chain reaction (qRT-PCR) of TSWV nucleocapsid (N) RNA to actin RNA was performed on individuals to estimate virus titer. TSWV titer in L1 thrips exposed to TSWVinfected transgenic plants for $24 \mathrm{~h}$ was significantly lower $(P \leq$ 0.0002) than L1 thrips exposed to nontransgenic plants in all biological replications of the experiment (Fig. 4), indicating a robust capacity of the transgenic plants to inhibit acquisition and infection of the vector by TSWV. We found that the number of L1 thrips infected with TSWV was reduced when fed on transgenic tissue for all three replications of the experiment $(6 / 12,0 / 12$, and $2 / 12$ versus $12 / 12,11 / 12$, and $11 / 12$, respectively). In accordance, TSWV-N cycle threshold values were statistically different between treatments $(P<0.0001$, MannWhitney tests). Therefore, transgenic plants have an effect on the number of L1 thrips infected with TSWV and on the level of infection within individual thrips.

\section{ELISA of plant tissue used for AAP}

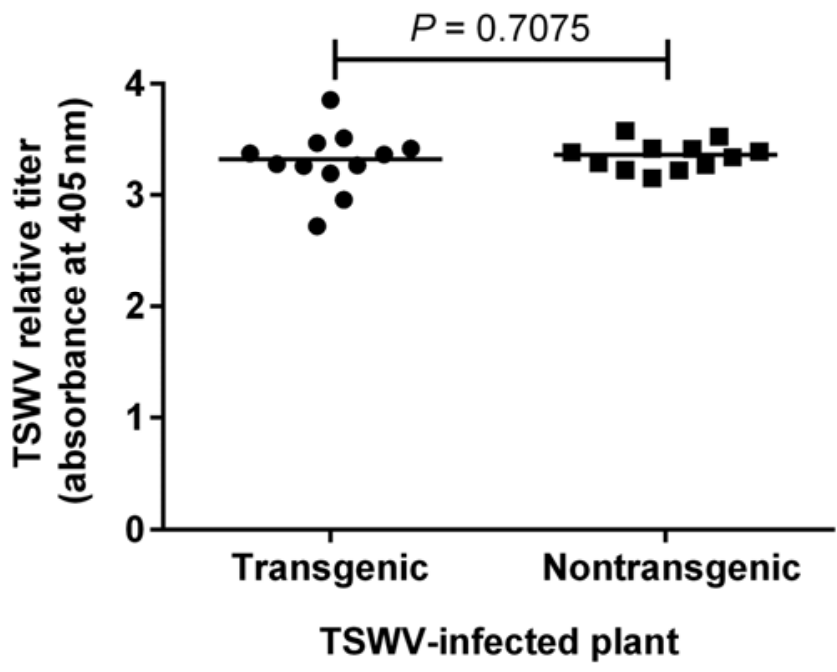

Fig. 3. Detection of TSWV nucleocapsid protein (N) by double-antibody sandwich enzyme-linked immunosorbent assay in tissue used for thrips acquisition access period. The graph depicts 12 data points (replicates) per treatment out of four independent experiments. The horizontal line indicates the median of the data points. Medians between the two treatments (transgenic or nontransgenic) were compared by the Mann-Whitney test.

\section{F. occidentalis cohorts show reduced transmission of TSWV when acquired \\ from transgenic $G_{\mathrm{N}}-\mathrm{S}$ ::GFP tomato plants.}

Transmission assays were performed to determine whether reduced titers in larval thrips fed on transgenic plants translated into reduced transmission efficiency by adults. Over three independent replications of the experiment, the proportions of transmitting adult thrips (i.e., efficiency of transmission) fed on $\mathrm{G}_{\mathrm{N}}-\mathrm{S}$ transgenics as larvae were significantly lower $(P=$ 0.0003 , median $=0 \%$ ) than those fed on nontransgenic tissues (median $>60 \%$ ), given a 48 -h inoculation access period (Fig. 5; Supplementary Table S2). These results show that the lower virus titers detected $24 \mathrm{~h}$ after larval acquisition of the virus from plants resulted in fewer individuals capable of transmitting the virus as adults.

The negative effect of $\mathrm{G}_{\mathrm{N}}-\mathrm{S}$ transgenics on virus accumulation in larvae persisted to adulthood. Provided only a 24-h access on TSWV-infected transgenics, larvae developed to adults that harbored four-log lower normalized levels of TSWV N RNA (median $=0.0004$ ) compared with those result-

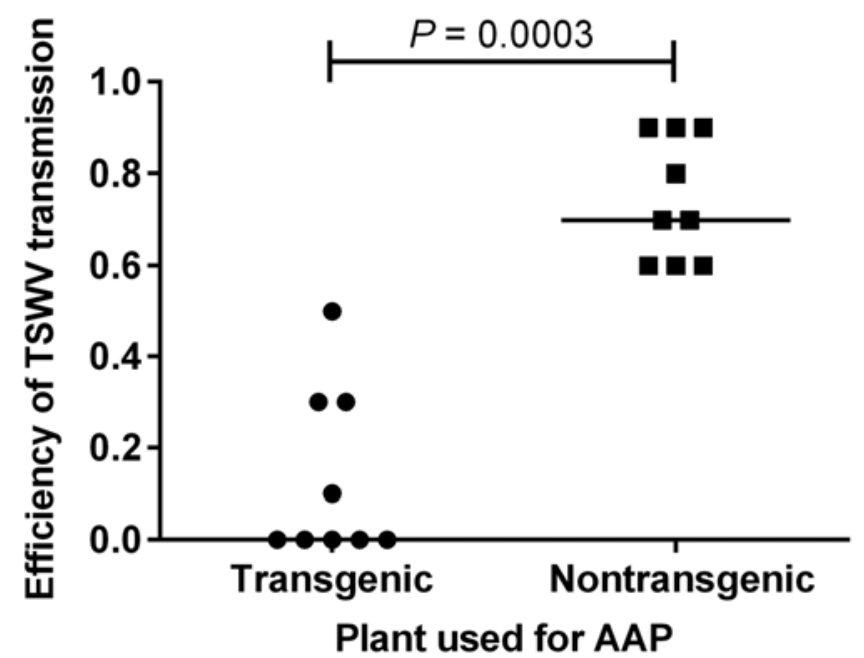

Fig. 5. Efficiency of transmission of TSWV by adult Frankliniella occidentalis individuals fed as larvae on transgenic and nontransgenic TSWVinfected plant tissue. Each data point represents the efficiency of transmission for 10 thrips tested individually for TSWV transmission by a 48-h inoculation access period on leaf discs of Datura stramonium. Treatments are significantly different at $P=0.0003$ as determined by the Mann-Whitney test.

\section{Exp A}

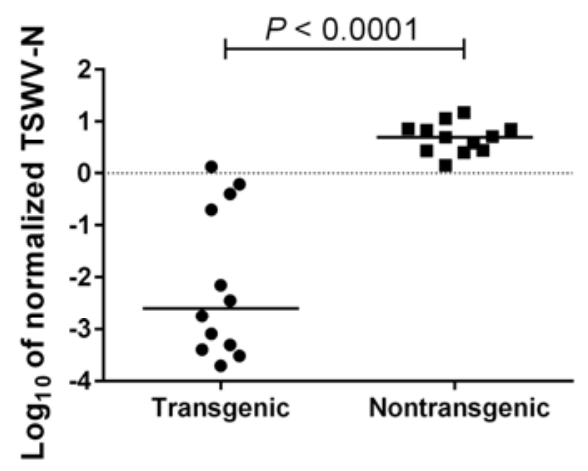

\section{$\operatorname{Exp} B$}

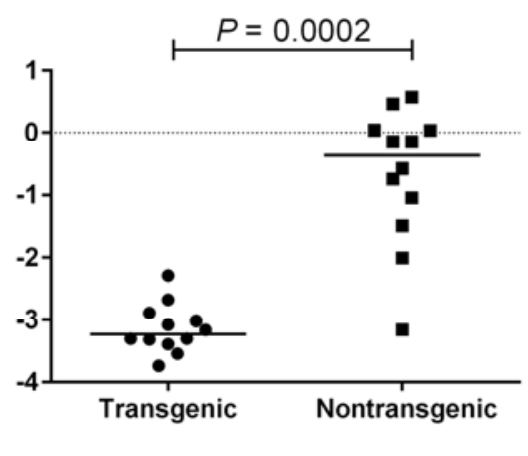

$\operatorname{Exp} C$

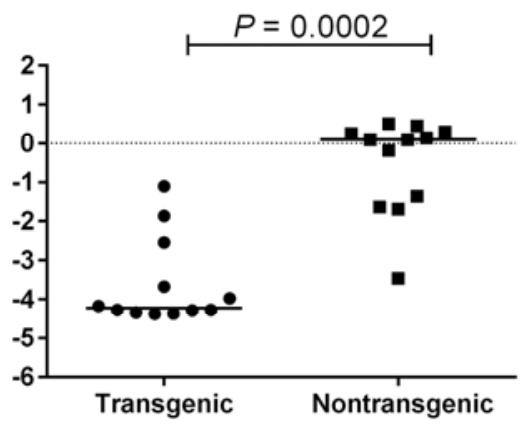

Plant used for AAP

Fig. 4. Normalized abundance ( $\log _{10}$ transformed) of TSWV nucleocapsid protein $(N)$ RNAs in larval thrips fed in transgenic and nontransgenic TSWV-infected plants. Larval thrips ( 0 to $18 \mathrm{~h}$ old) were exposed to a $\mathrm{G}_{\mathrm{N}^{-}} \mathrm{S}:$ :GFP transgenic plant or to a nontransgenic plant, both TSWV-infected, and allowed to feed for a 24-h acquisition access period. A second 24-h feeding period was done on green bean and sampled for quantitative reverse-transcriptase polymerase chain reaction. Twelve thrips per treatment and three independent experiments are shown. Virus abundance in thrips fed on the transgenic plant was significantly different $(P \leq 0.0002)$ from thrips fed on nontransgenic plant as determined by the Mann-Whitney test. 
ing from larvae fed on nontransgenics (median $=6.81)$, with an overall significance between treatment groups $(n=12, P<$ $0.0001)$, as well as significant treatment differences within each biological replicate (Fig. 6) $(P<0.0073)$. Significant associations between larval and adult titers (Fig. 7A) $\left(r_{s}=\right.$ $0.98, P<0.0001)$ were determined, and larval titer was significantly associated with transmission efficiency as adults (Fig. $\left.7 \mathrm{~B}, r_{s}=0.92, P<0.0001\right)$. Together, these findings support the hypothesis of a dose-dependent relationship between viral load and transmission efficiency in the virus-vector interaction, and underscore the significance of $\mathrm{G}_{\mathrm{N}}-\mathrm{S}$ transgenics as a possible strategy to control disease spread.

\section{DISCUSSION}

Interference with the initial steps of a pathogen-vector interaction provides an opportunity to inhibit transmission of the pathogen. We demonstrated the utility of a plant transgenicsbased approach to disrupt the transmission cycle of a plant virus by effectively reducing virus acquisition by the insect vector and subsequent viral loads. The results herein demonstrate that plant-expressed $\mathrm{G}_{\mathrm{N}}$ glycoprotein of TSWV interfered with the capacity of the thrips vector, $F$. occidentalis, to harbor and transmit the virus. Additionally, these results provide further support for $\mathrm{G}_{\mathrm{N}}$ as an important determinant of the virus-vector interaction (Sin et al. 2005; Whitfield et al. 2004). $\mathrm{G}_{\mathrm{N}}-\mathrm{S}$ transgenic plants enable a new and promising option to include in integrated management schemes for sustainable and long-term control of TSWV epidemics. Future research resulting from our findings includes the need to study the effect of the transgenic plants in the transmission of other tospoviruses in tomato or transmission of TSWV by other thrips species. Moreover, other susceptible crop species or ornamental plants may also be transformed following this approach.

The cytological and quantitative evaluation of the $\mathrm{G}_{\mathrm{N}}-\mathrm{S}$ expression in transgenic tissue furthers the understanding of the TSWV-plant interaction and has implications for use of these transgenics for virus control. One possible outcome of expressing recombinant viral RNA in plants and challenging these plants with wild-type virus is resistance triggered by RNA interference and subsequent degradation of wild-type viral RNA (Lindbo and Dougherty 2005). Such a phenotype was not observed in this study, 15 days after TSWV inoculation and, subsequently, when tissue was sampled for acquisition experiments. Transgenic expression of $\mathrm{G}_{\mathrm{N}}-\mathrm{S}$ had no apparent effect on the stability or pattern of TSWV infection of the trans-
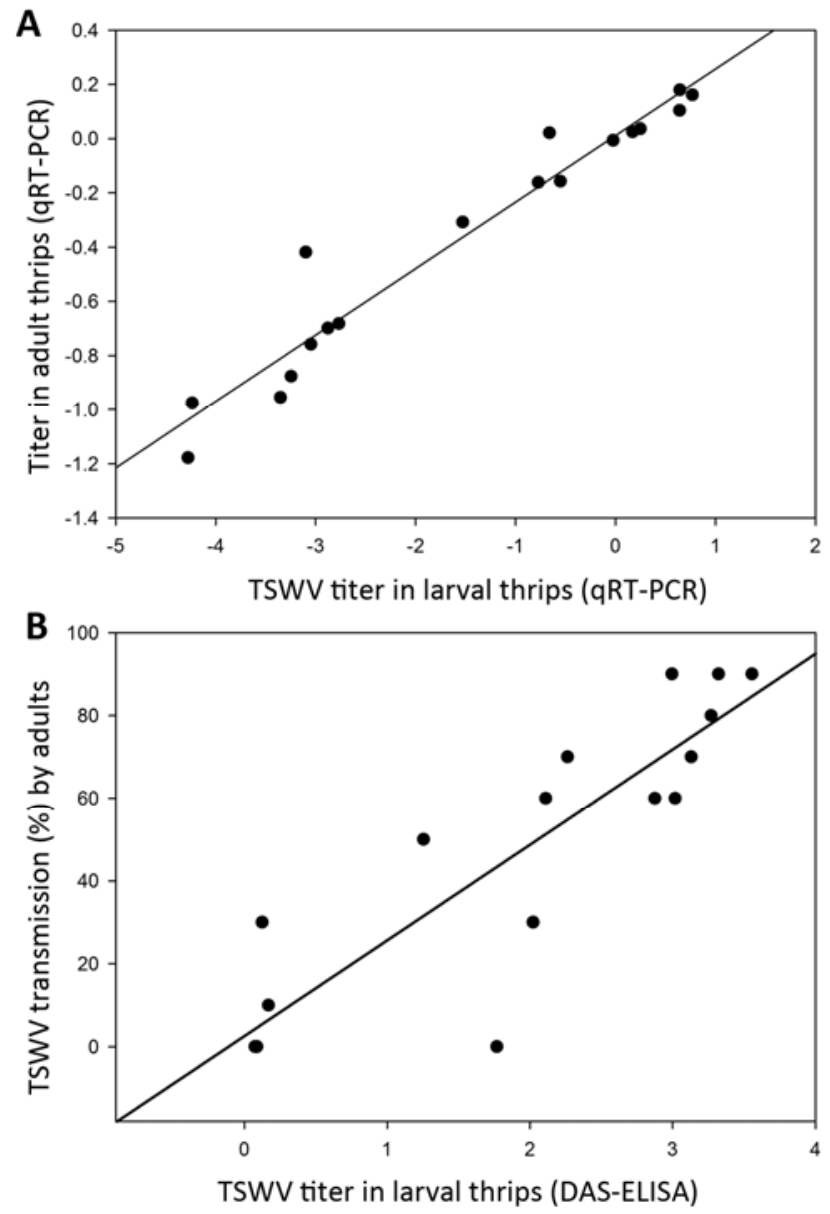

Fig. 7. Relationship between TSWV titer in larval Frankliniella occidentalis cohorts and the corresponding TSWV titer or transmission in adult thrips. A, TSWV titer was measured as normalized abundance of TSWV nucleocapsid protein $(\mathrm{N})$ transcripts by quantitative reverse-transcriptase polymerase chain reaction (qRT-PCR) for individual larval and adult thrips, and four individuals (adults and larvae) were analyzed per cohort. Each data point represents the median value (out of four individuals tested) for larvae or adults per cohort; Spearman's rank correlation test, $r_{s}=0.9794$ $(P<0.0001)$. B, TSWV titer was determined for each cohort by doubleantibody sandwich enzyme-linked immunosorbent assay (DAS-ELISA) from a pooled sample of 15 larvae and efficiency of transmission was determined for each cohort from TSWV transmission by 10 individual adults in a 48-h inoculation access period; Spearman's rank correlation test, $r_{s}=$ $0.9152(P<0.0001)$.
$\operatorname{Exp} A$

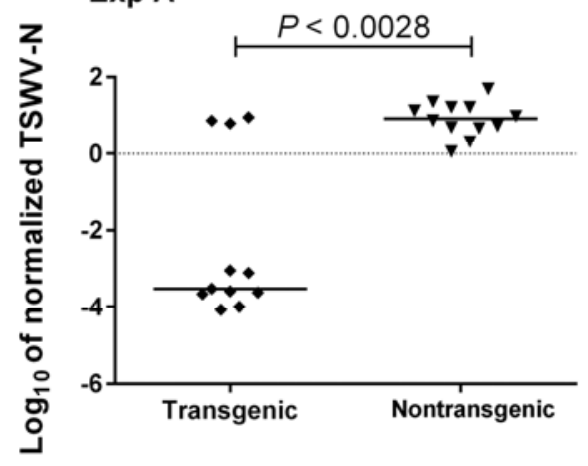

$\operatorname{Exp} B$

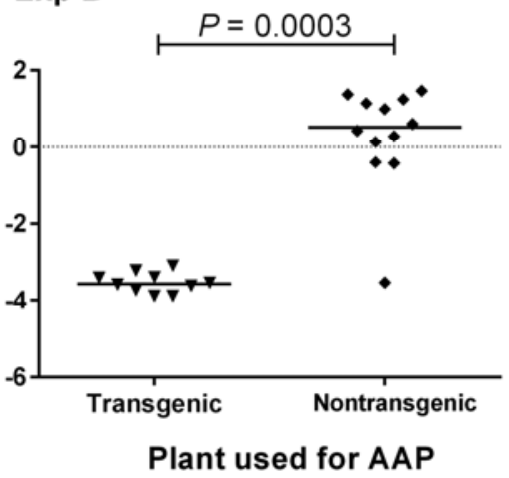

$\operatorname{Exp} C$

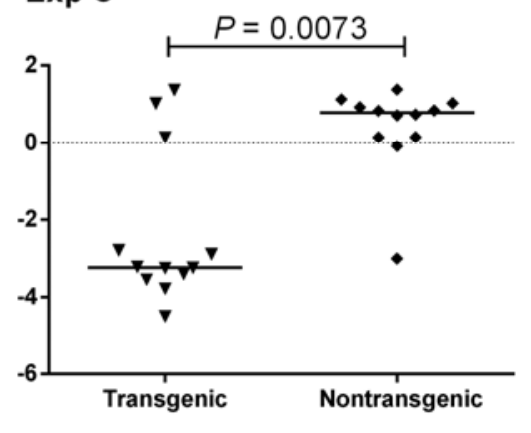

Fig. 6. Normalized abundance ( $\log _{10}$ transformed) of TSWV nucleocapsid protein $(\mathrm{N})$ RNAs in 24-h post-adult eclosion thrips fed as larvae in transgenic and nontransgenic TSWV-infected plants. Larval thrips (0 to $18 \mathrm{~h}$ old) were exposed to a $\mathrm{G}_{\mathrm{N}^{-}} \mathrm{S}:$ : GFP transgenic plant or to a nontransgenic plant, both TSWVinfected, and allowed to feed for a 24-h acquisition access period. Adult thrips ( $24 \mathrm{~h}$ old) reared from these larvae were given a 48 -h inoculation access period on Datura stramonium leaf discs and then sampled for quantitative reverse-transcriptase polymerase chain reaction. Twelve thrips per treatment and three independent experiments are shown. Virus abundance in thrips fed on the transgenic plant was significantly different $(P \leq 0.0073)$ from thrips fed on nontransgenic plant as determined by the Mann-Whitney test. 
genics used in acquisition and transmission assays. TSWV $\mathrm{N}$ protein was detected 15 days after inoculation in both transgenic and nontransgenic plants and systemic movement and infection occurred in both cases. Virus symptomatology and distribution was similar in the TSWV-infected transgenic and nontransgenic plants. The TSWV glycoproteins and the movement protein, NSm, are encoded on the M RNA segment. The widespread distribution of virus in the transgenic plants suggests that the $\mathrm{M}$ genome segment was not functionally silenced. In addition, infection had no apparent effect on accumulation of the recombinant protein in the tissue. Finally, given the plant-to-plant variation in the amount of recombinant protein produced in the transgenic lines tested in this study, it is likely that a higher amount of $\mathrm{G}_{\mathrm{N}}-\mathrm{S}$ may be achieved by selecting through several generations of the higher-expressing plants to produce more efficacious control.

The results on TSWV acquisition and subsequent transmission by $F$. occidentalis indicate a dose-dependent relationship in the virus-vector interaction, as was previously proposed by Rotenberg and associates (2009). Although few reports study the quantitative aspects of plant virus acquisition and transmission, the data support a quantitative parameter involved in the phenomenon for plant viruses ( $\mathrm{Ng}$ et al. 2004). In our system, it appears that the number of virus particles that start the infection makes a difference in terms of later virus titer in adults (Fig. 7A) and transmission by the individual thrips (Fig. 7B). We hypothesize that the initial infection of the midgut requires reaching certain titer thresholds to spread and potentially reach the salivary glands during a specific time or development window. The virus-vector interaction at the dose level and the host cellular response to virus replication in this system have just begun to be characterized (Badillo-Vargas et al. 2012; Rotenberg and Whitfield 2010; Rotenberg et al. 2009). Further research is required to understand the interplay between TSWV and thrips host cell responses to it, and how these interactions will define vector competence of thrips, as has been suggested for mosquito vectors of animal-infecting viruses (Keene et al. 2004; Khoo et al. 2010; Sanchez-Vargas et al. 2009). A balance may be reached between the virus replication cycle and thrips defense pathways which may vary depending on the level of initial infection.

We showed that transgenic tomato plants expressing a recombinant form of the ectodomain of TSWV G $\mathrm{G}_{\mathrm{N}}$ glycoprotein, $\mathrm{G}_{\mathrm{N}}-\mathrm{S}$, interfered with TSWV acquisition and transmission by western flower thrips. The results contribute to the hypothesis that $\mathrm{G}_{\mathrm{N}}$ is the attachment protein of the virus (Whitfield et al. 2004). Additionally, these transgenic plants are tools for further studying the virus-vector interaction and transmission specificity between virus and vector species. Overall, the results herein exemplify how the understanding of the molecular aspects of plant virus-vector interactions enable exploitation of the elements of the system to develop novel and ecologically sound approaches to control the spread of plant viruses. Moreover, this understanding and application can be broadened and adjusted for the control of other plant viruses and contribute to understanding and control of animal- and human-infecting counterparts: other arthropod-vectored bunyaviruses.

\section{MATERIALS AND METHODS}

\section{Construction of $\mathrm{G}_{\mathrm{N}}-\mathrm{S}:$ : GFP expression clone and plant transformation.}

The sequence corresponding to the soluble form of TSWV glycoprotein $\mathrm{G}_{\mathrm{N}}$ was amplified from plasmid pGF7 (Adkins et al. 1996) with primers General Wt/S ntl-31 F (5'-CACCATGA GAATTCTAAAACTACTAGAACTAGTCG-3') and reverse primer $\mathrm{G}_{\mathrm{N}}-\mathrm{S}$ fusion $n t 895-930 R$ (5'-AATGCTTTTTGAATATT TGATTATGCAATCTCTAAC- $\left.3^{\prime}\right)$. $\mathrm{G}_{\mathrm{N}}$ soluble $\left(\mathrm{G}_{\mathrm{N}}-\mathrm{S}\right)$ included only the predicted ectodomain of the glycoprotein, excluding the transmembrane and cytoplasmic domains. A C-terminal fusion to enhanced GFP was done by cloning the amplification product into $\mathrm{pENTR/D-TOPO}$ vector and then into the expression vector pSITE-2NB (Chakrabarty et al. 2007) by means of Gateway cloning technology (Invitrogen, Carlsbad, CA, U.S.A.).

Tomato (Solanum lycopersicum L.) 'Moneymaker' cotyledon and hypocotyls explants were transformed via Agrobacterium tumefaciens (strain LBA 4404) carrying the $\mathrm{G}_{\mathrm{N}}-\mathrm{S}$ ::GFP expression clone (Park et al. 2003). Transgenic tomato plants were kept in a greenhouse within a temperature range of $25^{\circ} \mathrm{C}$ (day) to $23^{\circ} \mathrm{C}$ (night) at a light cycle of $16 \mathrm{~h}$ of light and $8 \mathrm{~h}$ of darkness. Tomato fruit were periodically harvested from the plants and stored at $4{ }^{\circ} \mathrm{C}$ until processing for seed extraction.

\section{Generation of peptide antibodies that recognize $\mathbf{G}_{\mathbf{N}}$.}

Three polyclonal peptide antibodies against TSWV $\mathrm{G}_{\mathrm{N}}$ were custom made during this work to enable detection of $\mathrm{G}_{\mathrm{N}}-\mathrm{S}$ by Western blot and triple-antibody sandwich (TAS)-ELISA (GenScript USA Inc., Piscataway, NY, U.S.A.). A polyclonal peptide rabbit anti- $\mathrm{G}_{\mathrm{N}}$ was custom made against a 14-aminoacid peptide (SQTPGTRQIREEES) and two independent goat anti- $\mathrm{G}_{\mathrm{N}}$ antibodies against another 14-amino-acid peptide (DKSAKIPKTNKRVR). The goat antibody was designed to recognize a conserved domain in tospovirus $\mathrm{G}_{\mathrm{N}}$ proteins and the rabbit antibody to target a peptide unique to TSWV. Both 14-amino-acid peptides localize to the $\mathrm{N}$-terminus region of $\mathrm{G}_{\mathrm{N}}$, starting at residue 78 and 251 , respectively, from the start methionine of the polyprotein.

\section{ELISA screening of transgenic plants.}

ELISA was used to test transgenic plants for the presence of $\mathrm{G}_{\mathrm{N}}$-S::GFP and NPTII enzyme. Presence of NPTII was assayed by a DAS-ELISA, using a commercial detection kit (Agdia Inc., Elkhart, IN. U.S.A.), following the recommendations of the manufacturer. The presence of $\mathrm{G}_{\mathrm{N}}-\mathrm{S}$ protein fusion to GFP was tested by TAS-ELISAs using either i) goat and rabbit peptide polyclonal antibodies generated against the ectodomain of $\mathrm{G}_{\mathrm{N}}$ protein (GeneScript USA Inc.) or ii) goat peptide polyclonal antibodies against $\mathrm{G}_{\mathrm{N}}$ in combination with a rabbit polyclonal antibody against GFP (Invitrogen). In addition, the presence of transgenes and expression of full-length genes was confirmed by PCR and RT-PCR, respectively (data not shown).

Plant material for ELISA confirmation of protein expression consisted of a leaf disc (diameter approximately $13 \mathrm{~mm}$ ) that was cut from the apical leaflet of the youngest completely developed leaf (leaf node number three) of each tomato plant ( 3 weeks old). The leaf disc was ground in $1 \mathrm{ml}$ of general extraction buffer (GEB; Agdia Inc.). A working volume of $100 \mu \mathrm{l}$ per well was used for the different steps of the ELISA. i) For the anti- $\mathrm{G}_{\mathrm{N}}$ TAS-ELISA, the polyclonal rabbit anti- $\mathrm{G}_{\mathrm{N}}$ antibody was the coating antibody used at a concentration of $0.4 \mu \mathrm{g} / \mathrm{ml}$. The polyclonal goat anti- $\mathrm{G}_{\mathrm{N}}$ antibodies number 163 and 164 , at $0.2 \mu \mathrm{g} / \mathrm{ml}$, were used as secondary antibodies. ii) For the anti- $\mathrm{G}_{\mathrm{N}} / \mathrm{GFP}$ TAS-ELISA, the polyclonal goat anti- $\mathrm{G}_{\mathrm{N}}$ antibodies number 163 and 164 , diluted $0.4 \mu \mathrm{g} / \mathrm{ml}$ each, were used as coating antibodies. A commercial polyclonal rabbit antiGFP (Invitrogen) diluted to $0.8 \mu \mathrm{g} / \mathrm{ml}$ was used as the secondary antibody. In the NPTII ELISA, the cut-off value to declare a sample positive corresponded to two times the mean of negative controls and, for the $\mathrm{G}_{\mathrm{N}}$-S::GFP ELISAs, the cut-off value corresponded to the mean of negative controls plus three times the standard deviation of the negative samples.

Quantification of recombinant protein in transgenic plants.

The amount of recombinant protein $\left(\mathrm{G}_{\mathrm{N}}-\mathrm{S}:\right.$ :GFP) in $17 \mathrm{~T} 1$ transgenic plants was estimated using a quantitative GFP 
ELISA (MaxDiscovery green fluorescent protein ELISA kit; Bioo Scientific, Austin, TX, U.S.A.). The T1 plants analyzed were 1 plant from $T 0 \mathrm{G}_{\mathrm{N}}-\mathrm{S}:$ GFP number 3,2 from $\mathrm{G}_{\mathrm{N}}-\mathrm{S}:$ :GFP number 6,1 from $\mathrm{G}_{\mathrm{N}}-\mathrm{S}:$ :GFP number 7,12 from $\mathrm{G}_{\mathrm{N}}-\mathrm{S}:$ :GFP number 9 , and 1 from $\mathrm{G}_{\mathrm{N}}-\mathrm{S}:$ :GFP number 11 . Per every molecule of recombinant fusion protein there was one molecule of GFP; therefore, the amount of GFP in the plant tissue was an indirect measurement of the amount of the recombinant protein. Transgenic leaf tissue was sampled at $500 \mathrm{mg} /$ plant and ground in $0.5 \mathrm{ml}$ of protein extraction buffer included in the kit. The samples were treated and the ELISA conducted as indicated in the manufacturer's protocol. Total soluble protein per sample was quantified using Pierce BCA Protein Assay Kit (Thermo Scientific, Rockford, IL, U.S.A.) and standardized to total soluble protein at $3 \mathrm{mg} / \mathrm{ml}$.

One mole of $\mathrm{G}_{\mathrm{N}} \mathrm{S}$ ::GFP contains one mole of GFP; therefore, to estimate the amount of $\mathrm{G}_{\mathrm{N}}-\mathrm{S}:$ :GFP protein in each sample, the following formula was used: grams of $\mathrm{G}_{\mathrm{N}} \mathrm{S}:$ : GFP = grams GFP $\times 63,416 / 23,283$, were $63,416 / 23,283$ corresponds to the ratio between the formula weight of $\mathrm{G}_{\mathrm{N}}-\mathrm{S}:$ :GFP and GFP, respectively. To compare the relative amount of recombinant protein among plants, the amount (in nanograms) of $\mathrm{G}_{\mathrm{N}^{-}}$ $\mathrm{S}:$ GFP was expressed per milligram of total soluble protein in the sample.

\section{Sodium dodecyl sulfate polyacrylamide gel electrophoresis and Western blots.}

Protein expression was confirmed by separation of total protein extracts by sodium dodecyl sulfate polyacrylamide gel electrophoresis and detection by Western blot, as previously described (Whitfield et al. 2004). Primary antibodies were polyclonal peptide rabbit anti- $\mathrm{G}_{\mathrm{N}}$ and polyclonal rabbit anti-GFP (Invitrogen), diluted in phosphate-buffered saline (PBS) supplemented with 5\% nonfat dry milk (NFDM) at 1:2000 and 1:2500, respectively, and incubated for $2 \mathrm{~h}$. Secondary horseradish peroxidase-conjugated antibodies (Bio-Rad, Hercules, CA, U.S.A.) were diluted 1:5000 and incubated for $1 \mathrm{~h}$. Three rinses, each $100 \mathrm{ml}$ of PBS Tween and 5\% NFDM for $5 \mathrm{~min}$, were done between incubations with antibodies. Western blots were visualized with ECL Plus Western blotting detection system (GE Healthcare, Little Chalfont, BKM, U.K.).

\section{Fluorescence microscopy of transgenic tissue.}

The presence of the GFP-fused recombinant protein in the transgenic leaf tissue (abaxial surface) was evaluated by fluorescence microscopy of leaf sections $(0.5$ by $0.5 \mathrm{~cm})$ mounted in distilled water. The plant leaf tissue was observed by confocal microscopy (Zeiss Axiovert 200M microscope equipped with a Zeiss LSM 510 META system or a LSM 700 Confocal Laser Scanning microscope with Zen Efficient Navigation software).

\section{Challenge of $\mathbf{G}_{\mathbf{N}}-S:$ :GFP transgenic plants with TSWV.}

Three-week-old transgenic $\mathrm{G}_{\mathrm{N}}-\mathrm{S}$ ::GFP tomato plants that tested positive for the presence of the recombinant protein were inoculated with TSWV in order to evaluate the response of the plants to TSWV infection and to evaluate whether $\mathrm{G}_{\mathrm{N}^{-}}$ $\mathrm{S}:$ GFP is detectable in plant tissue after virus infection. In all, $18 \mathrm{~T} 1$ plants and 20 nontransgenic tomato plants were mechanically inoculated. For inoculation, leaf tissue from symptomatic, ELISA-positive tomato plants 3 weeks after inoculation was used as the virus source. Tomato plants were evaluated for virus presence 15 days after inoculation; apparently negative plants were reinoculated immediately and retested 15 days after the second inoculation.

Leaf tissue samples (1.3-cm-diameter disc) were collected from inoculated leaf tissue (old leaf) and from new systemic tissue (newly emerged leaf) for each plant. The terminal leaflet of the second true leaf (from bottom to top) was used to collect the mechanical inoculated leaf sample or local infection sample, and the terminal leaflet of the second younger leaf (from top to bottom) was collected as the systemic infection sample. Each leaf disc was homogenized in GEB and aliquots were tested separately for $\mathrm{G}_{\mathrm{N}}-\mathrm{S}: \mathrm{GFP}$ and TSWV $\mathrm{N}$ presence by TAS-ELISA (described previously) and DAS-ELISA (antiTSWV reagent set; Agdia Inc.) protocols, respectively. In the case of anti-TSWV DAS-ELISA, samples were considered positive when the absorbance value was higher than three times the mean absorbance value of the negative controls (noninoculated, healthy tomato plants of the same age as the inoculated ones).

\section{TSWV acquisition test on transgenic tissue.}

To determine the effect of transgenic tomato plants on TSWV acquisition by thrips, four independent experiments were conducted. For each experiment, leaflets (leaf node six from the top of the plant) from TSWV-infected transgenic and nontransgenic plants were placed in $15 \%$ agar plates. For each experiment, each treatment (transgenic or nontransgenic) was replicated three times (plates). Transgenic plants used for acquisition and transmission assays were confirmed to be TSWV positive and to harbor recombinant protein 15 days after inoculation. Moreover, fluorescence observations of the TSWVinfected plants confirmed the presence of $\mathrm{G}_{\mathrm{N}}-\mathrm{S}: \mathrm{GFP}$ in these plants. Plants $\mathrm{G}_{\mathrm{N}}-\mathrm{S}$ ::GFP number 9.302 (a $\mathrm{T} 1$ plant derived from T0 plant number 9) and nontransgenic number 113 were used in experiment one, and plants $\mathrm{G}_{\mathrm{N}^{-}} \mathrm{S}:$ : GFP number 9.517 (another T1 plant derived from T0 plant number 9) and nontransgenic-C were used for the other three experiments. Plants $\mathrm{G}_{\mathrm{N}}-\mathrm{S}:$ :GFP number 9.302 and nontransgenic number 113 were mechanically inoculated and plants $\mathrm{G}_{\mathrm{N}}$-S::GFP number 9.517 and nontransgenic-C were thrips inoculated with TSWV and confirmed by ELISA to be positive for TSWV and $\mathrm{G}_{\mathrm{N}} \mathrm{S}$ ::GFP presence 15 days after inoculation. For the acquisition of virus, L1 thrips 0 to $18 \mathrm{~h}$ old were placed on plant tissue that was contained in petri plates with $15 \%$ water agar and sealed with parafilm. The plates were kept at an incubator $\left(25^{\circ} \mathrm{C}\right.$, with a photoperiod of $12 \mathrm{~h}$ of light and $12 \mathrm{~h}$ of darkness) for a $24-\mathrm{h}$ AAP. The larval thrips were moved to plastic cups with green bean pods for another 24-h period to allow virus replication inside the thrips and clearing of TSWV-infected plant tissue from the gut lumen. From each cup (replicate), 15 thrips were collected into a 1.5-ml microcentrifuge tube and homogenized with a micropestle in $150 \mu \mathrm{l}$ of ice-cold GEB. Samples were vigorously vortexed (30 s), incubated on ice for $30 \mathrm{~min}$, and tested by DAS-ELISA (Agdia Inc.) for TSWV presence. Additionally, plant tissue (a leaf disc, diameter approximately 13 $\mathrm{mm}$ ) was collected after the AAP from each replicate plate and tested for TSWV infection by DAS-ELISA in order to compare the relative virus titer in plant tissue used for AAP. Control thrips not exposed to TSWV-infected tissue were also sampled. Thrips cups were maintained in an incubator and fresh green beans added until adult eclosion (8 to 9 days). ELISA absorbance values for thrips (15 pooled individuals) or for plant tissue used for AAP were compared by treatment (TSWV-infected versus healthy) by the Mann-Whitney test in GraphPad Prism (v.5.04; GraphPad Software, La Jolla, CA, U.S.A.).

\section{Determination of TSWV acquisition by qRT-PCR.}

To determine the normalized abundance of TSWV $\mathrm{N}$ transcripts in larval or adult thrips after an AAP on transgenic and nontransgenic TSWV-infected tissues, four thrips were collected per replication $24 \mathrm{~h}$ after an AAP (L1 thrips 42 to $50 \mathrm{~h}$ 
old) or adult thrips immediately after a 48-h inoculation access period for three independent experiments. The single thrips were placed into individual RNase-free $1.7-\mathrm{ml}$ microcentrifuge tubes, flash frozen in liquid nitrogen, and stored at $-80^{\circ} \mathrm{C}$. RNA was extracted from individual thrips, real-time qRT-PCR was done, and TSWV N normalized abundance was calculated, as described previously (Rotenberg et al. 2009). The normalized abundance of TSWV N RNAs to actin expression (internal reference) values were $\log _{10}$ transformed and compared by experiment between treatments (TSWV-exposed versus healthy-tissueexposed) by the Mann-Whitney test in GraphPad Prism. The difference in TSWV abundance between thrips exposed to nontransgenic or transgenic plants was estimated for larval or adult thrips by dividing the nontransgenic by the transgenic median normalized TSWV abundance value calculated for all biological replicates.

\section{Inoculation access period.}

Adult thrips (24 h after eclosion, 10 individuals per replicate) from each thrips cohort (three independent experiments) exposed to transgenic and nontransgenic TSWV-infected tissue were individually tested for transmission of TSWV in a 48-h period, as previously described (Rotenberg et al. 2009). Each experiment included three biological replicates for transgenic and for nontransgenic tissue, for a total of 60 thrips per experiment. Four thrips per replicate per experiment were randomly sampled for qRT-PCR after the inoculation access period. Normalized TSWV N RNA values ( $\log _{10}$ transformed) were compared by experiment between treatments (TSWV-exposed versus healthy-tissue-exposed) by the Mann-Whitney test in GraphPad Prism. The efficiencies of TSWV transmission by groups of 10 adult thrips per replicate per experiment were compared between treatments (fed as larvae on transgenic plant tissue versus fed on nontransgenic plant tissue) by the Mann-Whitney test in GraphPad Prism.

\section{Correlation analyses for virus titer in larval thrips and virus titer or transmission in adults.}

Correlation analyses in Figure 7 were done with the Spearman's rank correlation coefficient in GraphPad Prism (v.6.00; GraphPad Software) and the figures were generated with SigmaPlot 12.0. For Figure 7A, the value of normalized abundance of TSWV N RNAs (median out of four individual thrips) tested per cohort of thrips exposed to TSWV-infected transgenic and nontransgenic plants was scatter graphed (XY) and analyzed by Spearman rank correlation coefficient to test the correlation between TSWV abundance in larval thrips and the corresponding virus abundance in adult thrips originating from the same AAP cohort. In Figure 7B, the relative titer of virus (determined by ELISA) in a pooled sample of 15 larval thrips was scatter graphed against the percentage of transmission of adult thrips (sample of 10 thrips per cohort, tested individually for transmission) originating from the corresponding AAP cohort as the 15 larval thrips.

\section{ACKNOWLEDGMENTS}

This research was supported by the National Research Initiative of the United States Department of Agriculture National Institute of Food and Agriculture grant number 2007-35319-18326. M. Montero-Astúa acknowledges the Tillman scholarship from Kansas State University and a supplementary scholarship received from Universidad de Costa Rica. The contents are solely the responsibility of the authors and do not necessarily represent the official views of the National Institute of Health (NIH). We thank P. Wangemann and J. Sanneman at Kansas State University for their technical support in confocal microscopy and the COBRE facility for confocal microscopy access (supported by grant number P20 RR017686 from NIH). Contribution no. 14-192-J from the Kansas Agricultural Experiment Station.

\section{LITERATURE CITED}

Adkins, S., Choi, T., Israel, B. A., and Bandla, M. D. 1996. Baculovirus expression and processing of Tomato spotted wilt topsovirus glycoproteins. Phytopathology 86:849-855.

Amin, P. W., Reddy, D. V. R., and Ghanekar, A. M. 1981. Transmission of Tomato spotted wilt virus, the causal agent of bud necrosis of peanut, by Scirtothrips dorsalis and Frankliniella schultzei. Plant Dis. 65:663-665.

Badillo-Vargas, I. E., Rotenberg, D., Schneweis, D. J., Hiromasa, Y., Tomich, J. M., and Whitfield, A. E. 2012. Proteomic analysis of Frankliniella occidentalis and differentially expressed proteins in response to Tomato spotted wilt virus infection. J. Virol. 86:8793-8809.

Chakrabarty, R., Banerjee, R., Chung, S.-M., Farman, M., Citovsky, V., Hogenhout, S. A., Tzfira, T., and Goodin, M. 2007. pSITE vectors for stable integration or transient expression of autofluorescent protein fusions in plants: Probing Nicotiana benthamiana-virus interactions. Mol. Plant-Microbe Interact. 20:740-750.

Culbreath, A. K., Todd, J. W., and Brown, S. L. 2003. Epidemiology and management of Tomato spotted wilt virus in peanut. Annu. Rev. Phytopathol. 41:53-75.

de Oliveira, A. S., Melo, F. L., Inoue-Nagata, A. K., Nagata, T., Kitajima, E. W., and Resende, R. O. 2012. Characterization of Bean necrotic mosaic virus: A member of a novel evolutionary lineage within the genus Tospovirus. PLoS One 7:e38634. Published online.

Evans, J. D., and Gunderson-Rindal, D. 2003. Beenomes to bombyx: Future directions in applied insect genomics. Genome Biol. 4:107.

Falk, B. W., and Tsai, J. H. 1985. Serological detection and evidence for multiplication of Maize mosaic virus in the planthopper, Peregrinus maidis. Phytopathology 75:852-855.

Gao, Y., Lei, Z., and Reitz, S. R. 2012. Western flower thrips resistance to insecticides: Detection, mechanisms and management strategies. Pest Manage. Sci. 68:1111-1121.

Guler, S., Guler, E., Caglayik, D. Y., Kokoglu, O. F., Ucmak, H., Bayrakdar, F., and Uyar, Y. 2012. A sandfly fever virus outbreak in the East Mediterranean region of Turkey. Int. J. Infect. Dis. 16:E244-E246.

Herder, V., Wohlsein, P., Peters, M., Hansmann, F., and Baumgaertner, W. 2012. Salient lesions in domestic ruminants infected with the emerging so-called Schmallenberg virus in Germany. Vet. Pathol. 49:588-591.

Jones, R. A. C. 2009. Plant virus emergence and evolution: Origins, new encounter scenarios, factors driving emergence, effects of changing world conditions, and prospects for control. Virus Res. 141:113-130.

Keene, K., Foy, B., Sanchez-Vargas, I., Beaty, B., Blair, C., and Olson, K. 2004. RNA interference acts as a natural antiviral response to O'nyongnyong virus (Alphavirus; Togaviridae) infection of Anopheles gambiae. Proc. Natl. Acad. Sci. U.S.A. 101:17240-17245.

Khoo, C. C. H., Piper, J., Sanchez-Vargas, I., Olson, K. E., and Franz, A. W. E. 2010. The RNA interference pathway affects midgut infectionand escape barriers for Sindbis virus in Aedes aegypti. BMC Microbiol. 10:130.

Kilpatrick, A. M., and Randolph, S. E. 2012. Zoonoses 2 Drivers, dynamics, and control of emerging vector-borne zoonotic diseases. Lancet 380:19461955.

Lindbo, J., and Dougherty, W. 2005. Plant pathology and RNAi: A brief history. Annu. Rev. Phytopathol. 43:191-204.

Liu, S., Sivakumar, S., Sparks, W. O., Miller, W. A., and Bonning, B. C. 2010. A peptide that binds the pea aphid gut impedes entry of Pea enation mosaic virus into the aphid hemocoel. Virology 401:107-116.

Lopez, C., Aramburu, J., Galipienso, L., Soler, S., Nuez, F., and Rubio, L. 2011. Evolutionary analysis of tomato $\mathrm{Sw}-5$ resistance-breaking isolates of Tomato spotted wilt virus. J. Gen. Virol. 92:210-215.

Mandal, B., Jain, R. K., Krishnareddy, M., Kumar, N. K. K., Ravi, K. S., and Pappu, H. R. 2012. Emerging problems of Tospoviruses (Bunyaviridae) and their management in the Indian Subcontinent. Plant Dis. 96:468-479.

Margaria, P., Ciuffo, M., and Turina, M. 2004. Resistance breaking strains of Tomato spotted wilt virus (Tospovirus-Bunyaviridae) on resistant pepper cultivars in Almeria (Spain). Plant Pathol. 5:71-82.

McMullan, L. K., Folk, S. M., Kelly, A. J., MacNeil, A., Goldsmith, C. S., Metcalfe, M. G., Batten, B. C., Albariño, C .G., Zaki, S.R., Rollin, P. E., Nicholson, W. L., and Nichol, S. T. 2012. A new Phlebovirus associated with severe febrile illness in Missouri. N. Engl. J. Med. 367:834-841.

Morse, J. G., and Hoddle, M. S. 2006. Invasion biology of thrips. Annu. Rev. Entomol. 51:67-89.

Naidu, R. A., Ingle, C. J., Deom, C. M., and Sherwood, J. L. 2004. The two envelope membrane glycoproteins of Tomato spotted wilt virus show differences in lectin-binding properties and sensitivities to glycosidases. Virology 319:107-117.

Ng, J., Tian, T., and Falk, B. 2004. Quantitative parameters determining whitefly (Bemisia tabaci) transmission of Lettuce infectious yellows virus and an engineered defective RNA. J. Gen. Virol. 85:2697-2707. 
Pappu, H. R., Jones, R. A. C., and Jain, R. K. 2009. Global status of tospovirus epidemics in diverse cropping systems: Successes achieved and challenges ahead. Virus Res. 141:219-236.

Park, S., Morris, J., Park, J., Hirschi, K., and Smith, R. 2003. Efficient and genotype-independent Agrobacterium- mediated tomato transformation. J. Plant Physiol. 160:1253-1257.

Reitz, S. R. 2009. Biology and ecology of the Western flower thrips (Thysanoptera: Thripidae): The making of a pest. Fla. Entomol. 92:7-13.

Riley, D. G., Joseph, S. V., Srinivasan, R., and Diffie, S. 2011. Thrips vectors of Tospoviruses. J. Integr. Pest Manage. 2:1-10.

Rotenberg, D., and Whitfield, A. E. 2010. Analysis of expressed sequence tags from Frankliniella occidentalis, the western flower thrips. Insect Mol. Biol. 19:537-551.

Rotenberg, D., Kumar, N. K. K., Ullman, D. E., Montero-Astúa, M., Willis, D. K., German, T. L., and Whitfield, A. E. 2009. Variation in Tomato spotted wilt virus titer in Frankliniella occidentalis and is association with frequency of transmission. Phytopathology 99:404-410.

Sanchez-Vargas, I., Scott, J. C., Poole-Smith, B. K., Franz, A. W. E., Barbosa-Solomieu, V., Wilusz, J., Olson, K. E., and Blair, C. E. 2009. Dengue virus type 2 infections of Aedes aegypti are modulated by the mosquito's RNA interference pathway. PLoS Pathog. 5:e1000299. Published online.

Scholthof, K. G., Adkins, S., Czosnek, H., Palukaitis, P., Jacquot, E., Hohn, T., Saunders, K., Candresse, T., Ahlquist, P., Hemenway, C., and Foster, G. D. 2011. Top 10 plant viruses in molecular plant pathology. Mol. Plant Pathol. 12:938-954.
Shao, C., Wu, J., Zhou, G., Sun, G., Peng, B., Lei, J., Jin, D., Chen, S., Upadhyaya, N. M., Waterhouse, P., and Gong, Z. 2003. Ectopic expression of the spike protein of Rice ragged stunt oryzavirus in transgenic rice plants inhibits transmission of the virus to insects. Mol. Breed 11:295-301.

Sin, S., McNulty, B. C., Kennedy, G. G., and Moyer, J. W. 2005. Viral genetic determinants for thrips transmission of Tomato spotted wilt virus. Proc. Natl. Acad. Sci. U.S.A. 102:5168-5173.

Sparks, W. O., Rohlfing, A., and Bonning, B. C. 2011. A peptide with similarity to baculovirus ODV-E66 binds the gut epithelium of Heliothis virescens and impedes infection with Autographa californica multiple nucleopolyhedrovirus. J. Gen. Virol. 92:1051-1060.

Sutherst, R. W. 2004. Global change and human vulnerability to vectorborne diseases. Clin. Microbiol. Rev. 17:136-173.

Walter, C. T., and Barr, J. N. 2011. Recent advances in the molecular and cellular biology of bunyaviruses. J. Gen. Virol. 92:2467-2484.

Whitfield, A. E., Ullman, D., E., and German, T., L. 2004. Expression, purification, and characterization of a soluble form of Tomato spotted wilt virus glycoprotein $\mathrm{G}_{\mathrm{N}}$. J. Virol. 78:13197-13206.

Whitfield, A. E., Ullman, D. E., and German, T. L. 2005. Tospovirusthrips interactions. Annu. Rev. Phytopathol. 43:459-489.

Whitfield, A. E., Kumar, N. K. K., Rotenberg, D., Ullman, D. E., Wyman, E. A., Zietlow, C., Willis, D. K., and German, T. L. 2008. A soluble form of the Tomato spotted wilt virus (TSWV) glycoprotein $\mathrm{G}_{\mathrm{N}}\left(\mathrm{G}_{\mathrm{N}}-\mathrm{S}\right)$ inhibits transmission of TSWV by Frankliniella occidentalis. Phytopathology 98:45-50. 